\title{
SEROLOGICAL STUDY FOR DETECTION OF NEW EMERGING ECTOPARASITES BORNE DISEASE (SCHMALLENBERGE VIRUSE) IN DUHOK PROVINCE - IRAQ
}

\author{
LOKMAN TAIB OMER AL-BARWARY \\ University of Duhok College of Veterinary Medicine
}

Received: 6 September 2018; Accepted: 27 September 2018

\begin{abstract}
Schmallenberg disease, an ectoparasite borne disease, is one of the most important emerging disease that discovered recently and was first reported in Germany in 2011. The disease affects animal industries through causing many clinical signs ranging from reduce milk production, weight loss to abortion and death of newborn animal. To our knowledge this is considered the first preliminary study on the presence of circulating Schmallenberg virus in Iraqi Kurdistan. In this research, only ELISA was used for detection of antibodies and antigens of the virus. Serological study showed that out of 192 animals, 16.1\% were tested positive. There was not significantly different between geographical places $(\mathrm{p}>0.05)$. However, this study showed that the incidence of abortion in sheep due to Schmallenberge virus was significantly different between geographical places ( $>0.05$ ). The overall incidence of abortion in this study was nearly about $47 \%$. The highest incidence was observed in shexan with at $90 \%$.
\end{abstract}

Key words: Schmallenberg virus, Sheep, ELISA, DUHOK

\section{INTRODUCTION}

Like other blood feeding Diptera, Culicoides species are vectors of pathogens that can cause a wide varietyof the disease in humans and animals. Biting midges, primarily the species Culicoidessonorensis, are considered a biological vector for transmission of pathogens (like bluetongue virus) in sheep and cattle in the United States of America. Bluetongue is a serious disease of ruminants (Bilk et al., 2012).

Recently, a new virus, which is an RNA virus, belongs to the Simbu-sero-group of the genus Orthobunya virus in the family Orthobunyaviridaeis called Schmallenberg virus. The virus is transmitted via biting midges. This new emerging virus causes clinical signs inruminants, such as a drop in milk yield, fever, diarrhea, abortions, and congenital malformations in newborn lambs, kids, and calves (Bilk et al., 2012; Hoffmann et al., 2012; Muskens et al., 2012).

Corresponding author: Dr. LOKMAN TAIB OMER E-mail address: Luqman_ommar@uod.ac

Present address: University of Duhok college of veterinary medicine
Hoffmann et al. (2012) Reportedclinical signs of unrecognized disease includesharpreductionof milk production, fever, and diarrhea in adult cows in northwestern Germany and Netherlands. Van Den Brom et al. (2012) Recorded some other clinical signs among ewes in Netherlands that gave birth of malformed lambs. Those clinical signs have not been reported in Europe previously. However, those ewes did not show any clinical signs during gestation period or at parturition.

Moreover, Helmer et al. (2013) described similar cases in goat flocks in spring 2012. In 2012, there were two major outbreaks SBV infection have been reported. In February, the first outbreakreportedin sheep herds and the second outbreak reported in cattle herds in May (Afonso et al., 2014). After these two outbreaks, few months later, the virus had spread over Western Europe with outbreaks in Belgium, France, Germany, Luxemburg, the Netherlands, parts of England and Switzerland. One year later, the disease reached northern Sweden (Conraths et al., 2013). From September, 2011 until April, 2013 more than 8000 laboratory cases had been confirmed with SBV in twenty European member states (Austria, Belgium, Croatia, Czech Republic, Denmark, Estonia, Finland, France, Hungary, Germany, Ireland, Italy, Latvia, 
Luxembourg, the Netherlands, Poland, Slovenia, Spain, Sweden, and the United Kingdom) and two countries in the European Free Trade Association area (Switzerland and Norway) (ANONYMUS, 2013). The number of SBV infected herds may be up to 300 times greater than the number of confirmedreported cases (Garigliany et al., 2012). Furthermore, SBV had been detected in twelve wild species, dog and 19 different species in zoos rather than domestic sheep, goats and cattle (EFSA, 2014)

Antibodies against SBV were found in Turkey (Azkur et al., 2013; TONBAK et al., 2016). Serological detection of SBV in aborted ewes in Duhok province might be explained byanimal importation or the illegal animal trade. The aim of this study here was to analyze samples from ewes and aborted fetuses to investigate the direct presence of SBVin Kurdistan Region /Iraq. Especially when this disease was recorded in Turkey (Azkur et al., 2013; TONBAK et al., 2016; Sukru T. et al., 2013).

\section{MATERIALS AND METHODS}

\section{Blood Samples}

Blood samples were collected from sheep of different age that had history of abortions or fertility problems from different flocks' in Duhok Province, between July and August in Kurdistan region in 2015. A total of 192 serum samples and 192 wholebloodsamples from 192 sheep were collected intubes without any anticoagulant and in tubes containing EDTA, respectively. For serum, tubes were centrifuged at $3000 \mathrm{rpm}$ for $10 \mathrm{~min}$. All samples were stored in tubesat $-20^{\circ} \mathrm{C}$ until further analyses.

\section{Serological test (ELISA)}

The samples were analyzed by the ID Screen Schmallenberg virus Competition Multi Species ELISA (ID-vet, France) according to the manufacture instruction (comtet $\mathrm{L}$ and Pourquir $\mathrm{P}$ 2013). This ELISA is developed for ruminants and other species. Briefly, the ID-vet ELISA testing procedure was as follow, serum, positive (PC) and negative (NC) controls were added to antibodies were present, an antibody-antigen complex, which masks the nucleoprotein epitopes, was formed. After incubation, conjugate that fixes to the free nucleoprotein epitopes was added. After washing steps, substrate solution and finally stop solution were added. The micro-plate was read at $450 \mathrm{~nm}$.
The optical density (OD) was recorded and the competition percentage ( $\mathrm{S} / \mathrm{N} \%)$ where $\mathrm{S}$ is the $\mathrm{OD}$ of the sample and $\mathrm{N}$ is the $\mathrm{OD}$ of the negative control, was calculated:

$\mathrm{S} / \mathrm{N} \%=\mathrm{OD}$ sample/OD negative control X 100

The results were interpreted as follows: S/N \% less than or equal to $40 \%$ were considered positive, greater than $50 \%$ negative, and between $40-50 \%$ as doubtful.

\section{Statistical analysis}

Before performing analysis, data were checked for normality and homogeneity of variance using residual plots and Bartlett's test, respectively. The prevalence of Schmallenberg virus and the incidence rate of abortion in sheep caused by Schmallenberg virus between geographical places were analyzed using logistic regression in Genstat $12^{\text {th }}$ Edition (VSN international Ltd, Hemel Hempsteadf, UK).

\section{RESULTS}

Serological method used for detection of new suspected diseases may be recently reached Middle East especially when an outbreak of this disease recorded in Turkey (TONBAK et al., 2016). Table (1 and 2) shows theresults obtained during serological investigation for 192 samples of aborted and non-aborted ewes having history of fertility problems collected from most parts of Duhok province especiallyfrom the areas that are close to Syria and Turkey border, which are the two main illegal entrances of animals. This illegal movement helps to transports some trans-boarding disease.

This study showed that the incidence of abortion in sheep due to Schmallenberg virus was significantly different between geographical places $(\mathrm{P}>0.001$; table 1). The overall incidence of abortion in this study was nearly about $47 \%$. There was a wild variation in the reported incidence of abortion between geographical places, with a range of 10$90 \%$. The highest incidence was observed in Shexan with at $90 \%$. It is interesting to note that West of Zakho and south of Sumel have reported the same rate of abortion in sheep $(60 \%)$ caused by Schmallenberg virus. 
Table 1: The incidence rate of abortion in sheep caused by Schmallenberg virusbetween different geographical places

\begin{tabular}{lcccc}
\hline Geographical place & No. of aborted & $\begin{array}{c}\text { No. of Non- } \\
\text { aborted }\end{array}$ & Total number & \% of abortion \\
\hline West of Zakho & 12 & 8 & 20 & 60.0 \\
North of Zakho & 16 & 19 & 35 & 45.7 \\
West of Sumel & 2 & 18 & 20 & 10.0 \\
South of Sumel & 18 & 12 & 30 & 60.0 \\
Duhok & 20 & 10 & 30 & 66.7 \\
Shexan & 18 & 2 & 20 & 90.0 \\
Amedy & 4 & 33 & 37 & 10.8 \\
Total & $\mathbf{9 0}$ & $\mathbf{1 0 2}$ & $\mathbf{1 9 2}$ & $\mathbf{4 6 . 9}$ \\
\hline
\end{tabular}

Also the results demonstrated that the prevalence of Schmallenberg virus was not significantly different between geographical places ( $\mathrm{P}>0.05$; table 2). The mean prevalence of Schmallenberg virus across the whole study was $16.1 \%$. The highest incidence was observed in West and North of Zakho at 30 and $20 \%$, respectively. Thereafter, the prevalence has been lower between $6-16 \%$.

Table 2: The prevalence of Schmallenberg virus across different geographical places.

\begin{tabular}{lcccc}
\hline Geographical place & Positive number & Negative number & Total number & \% \\
\hline West of Zakho & 6 & 14 & 20 & 30.0 \\
North of Zakho & 7 & 28 & 35 & 20.0 \\
West of Sumel & 3 & 17 & 20 & 15.0 \\
South of Sumel & 5 & 25 & 30 & 16.7 \\
Duhok & 2 & 28 & 30 & 6.7 \\
Shexan & 2 & 18 & 20 & 10.0 \\
Amedy & 6 & 31 & 37 & 16.2 \\
Total & $\mathbf{3 1}$ & $\mathbf{1 6 1}$ & $\mathbf{1 9 2}$ & $\mathbf{1 6 . 1}$ \\
\hline
\end{tabular}

\section{DISCUSSIONS}

Schmallenberg virus was first detected in autumn 2011 in dairy cattle in central Europe (Garigliany et al., 2012; Hoffmann et al., 2012; MĂNESCU et al., 2015). It was subsequently found in malformed lambs, kids, and calves in Germany (EFSA, 2014). The speed of SBV spreading across Europe in 2011 and 2012 was impressive, and thus the distribution of SBV to bordering countries was very likely. Currently, in Kurdistan there is no report about the detection of SBV.

Our results showed the competitive ELISA detected about $16.1 \%$ positive and its different rates in different area from Duhok Government (Table2). The rate of infection was higher in theareas near to Syrian border, and this rate decreased in far area this depend upon the concentration of imported animals especially illegal imported animal, the illegal movement of animals from Syria was increased after ISIS war.
This study reported the first time the existence of this disease in Kurdistan Region Duhok Governorate. Unfortunately, it is not sure that SBV is present in Kurdistan Region/Iraq since there is a risk for cross reactively with other simbu viruses. By the results in this study, it can only suggest that SBV or an SBV like virus is present in Kurdistan Region/Iraq. To confirm the result of this study, it is recommended to do further study especially in molecular using PCR or RT-PCR for detection of this virus, in addition to this, the sequencing which is important as well to confirm our results and causative agent of this diseasealso recommended.

\section{ACKNOWLEDGMENT}

The author indebted to Dr Nacheervan M. Ghaffar, Dr Zeravan M, Mr. Meqdad Ahmed and Mr. Bayar Amedy for them valuable comments and revision of the manuscript. 


\section{REFERENCES}

Afonso, A.; Abrahantes, J.C.; Conraths, F.; Veldhuis, A.; Elbers, A.; Roberts, H.; Van der Stede, Y.; Méroc, E.; Gache, K. and Richardson, J. (2014): The Schmallenberg virus epidemic in Europe-2011-2013. Preventive Veterinary Medicine, Special Issue: Schmallenberg Virus: Epidemiology of an Emerging Disease 2014; vol. 116, pp. 391-403,

Anonymus: (2013): Schmallenberg virus: AHVLA predicts similar losses in 2013. 2013; Vet. Rec. 172, 3 ,

Azkur, A.K.; Albayral, H.; Risvanli, A.; Pestil, Z.; Ozan, E.; Yilmaz, O.; Tonbak, S.; Cavunt, A.; Kadi, H.; Macun, H.C.; Acar, D.; Özenç, E.; Alparslan, S. and Bulut, H. (2013): Antibodies to Schmallenberg virus in domestic livestock in Turkey. Tropical Animal Health and Production, 2013; vol. 45, pp. 1825-1828,

Bilk, S.; Schulze, C.; Fischer, M.; Beer, M.; Hlinak, A. and Hoffmann, B. (2012): Organ distribution of Schmallenberg virus RNA in malformed newborns. Vet. Microbiol. 2012; 14, 236-238.

Comtet, L. and Pourquier, P. (IDvet, France) (2013): ID screen schmallenberg virus competition multi-species validation of a competive ELISA for the detection of antibodies diected against the schmallenberg virus nucleoprotein post present at the Epizone $7^{\text {th }}$ annual meeting Brussels Belgium.

Conraths, F.; Peters, M. and Beer, M. (2012): Schmallenberg virus, a novel orthobunyavirus infection in ruminants in Europe: Potential global impact and preventive measures. New Zeeland Veterinary Journal, 2012; vol. 61, pp. 63-67.

EFSA, (2014): Schmallenberg virus: state of Art. EFSA Journal, 2014; 12, 1-54.
Garigliany, M.-M.; Hoffmann, B.; Dive, M.; Sartelet, A.; Bayrou, C.; Cassart, D.; Beer, M. and Desmecht, D. (2012): Schmallenberg Virus in Calf Born at Term with Porencephaly, Belgium. Emerging Infectious Diseases, 2012; vol. 18, pp. 1005-1006.

Helmer, C.; Eibach, R.; Tegtmeyer, P.C.; HumannZiehank, E. and Ganter, M. (2013): Survey of Schmallenberg virus (SBV) infection in German goat flocks. Epidemiology \& Infection2013; vol. 141, pp. 2335-2345.

Hoffmann, B.; Scheuch, M.; Höper, D.; Jungblut, R.; Holsteg, M.; Schirrmeier, H.; Eschbaumer, M.; Goller, K.V.; Wernike, K.; Fischer, M.; Breithaupt, A.; Mettenleiter, T.C. and Beer, M. (2012): Novel Orthobunyavirus in Cattle, Europe, 2012; Emerging Infectious Diseases, 2012,18, 469-472.

Mănescu, M.A.; Bărăităreanu, S.; Gurău, M.R.; Daneş, D.N.D. Molecular tools available for the detection of schmallenberg-simbu group viruses.

Muskens, J.; Smolenaars, AJG. and Van der Poel, WHM.(2012): Diarrhea and loss of production on Dutch dairy farms caused by the Schmallenberg virus. Tijdschr Diergeneesk, 2012; 137: 112-115,

Sukru, T.; Azkur, A.K.; Pestil, Z.; Biyikli, E.; Abayli, H.; Baydar, E.M.H.W.; Van der, P. and Bulut, H. (2016): Circulation of Schmallenberg virus in Turkey, 2013. Turkish Journal of veterinary and animal science.2016; 40, pp. 175-180,

Tonbak, Ş.; Azkur, A.K.; Pestil, Z.; Biyikli, E.; Abayli, H.; Baydar, E. and Bulut, H. (2016): Circulation of schmallenberg virus in turkey, 2013. Turkish j. Vet. Anim. Sci. 40, 175-180.

Van Den Brom, R.; Luttikholt, S.J.M.; Lievaartpeterson, K.; Perkamp, N.H.M.T.; Mars, M.H.; Van Der Poel, W.H.M. and Vellema, P. (2012): Epizootic of ovine congenital malformations associated with Schmallenberg virus infection. Tijdschrift Voor Diergeneeskunde 2012; 137, 106-111.

\section{دراسة مصلية لكثف اول ظهور لمرض (Schmallenberg) الناقلة عن طريق طفيليات الخارجية في محافظة دهوك - عراق الن$$
\text { ل - لقعان عدر }
$$ \\ Email: Luqman_ommar@uod.ac Assiut University web-site: www.aun.edu.eg}

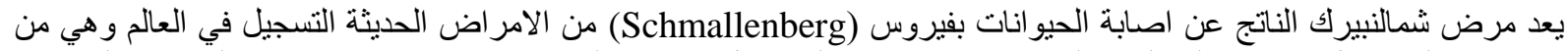

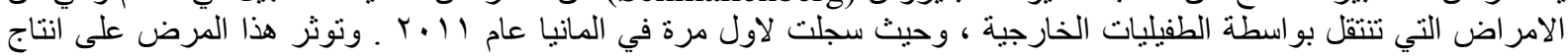

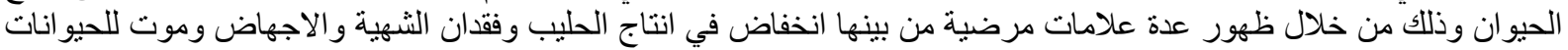

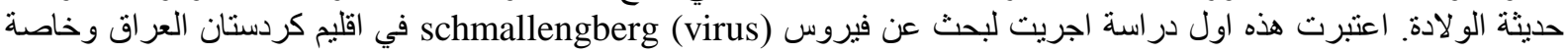

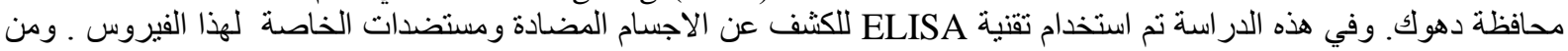

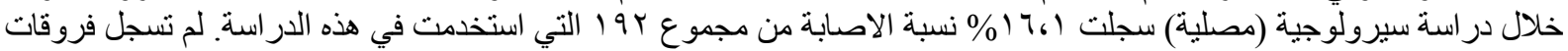

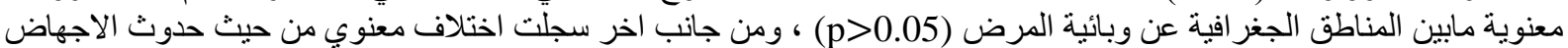

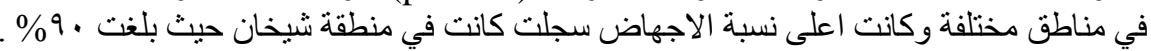

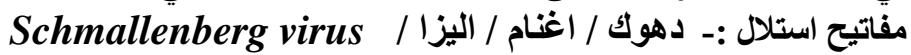

